\title{
Phenolic compounds, biological activities and trace elements of Capparis ovata var. canescens
}

Turgut Taşkın ${ }^{1 *}$, Duygu Taşkın², Muhammet Emin Cam ${ }^{3,4,5}$ \& Gizem Bulut ${ }^{6}$

1. Department of Pharmacognosy, Faculty of Pharmacy, Marmara University, Istanbul-Turkey; turguttaskin@marmara.edu.tr, ttaskin237@gmail.com

2. Department of Analytical Chemistry, Faculty of Pharmacy, University of Health Science, Istanbul-Turkey; duygu.taskin@sbu.edu.tr

3. Department of Pharmacology, Faculty of Pharmacy, Marmara University, Istanbul-Turkey; muhammet.cam@marmara.edu.tr

4. Department of Mechanical Engineering, University College London, Torrington Place, London WC1E 7JE, UK.

5. Center for Nanotechnology and Biomaterials Research, Marmara University, Istanbul-Turkey.

6. Department of Pharmaceutical Botany, Faculty of Pharmacy, Marmara University, Istanbul-Turkey; gizem.bulut@marmara.edu.tr

* Correspondence

$$
\text { Received 27-XII-2019. C Corrected 22-II-2020. Accepted 19-III-2020. }
$$

ABSTRACT. Introduction: Capparis species (Capparaceae), also called caper, grow naturally in various regions of the world. Caper is a plant with medicinal and aromatic properties. Flower buds, root bark, and fruits of the plant are used in folk medicine due to their analgesic, wound healing, cell regeneration, tonic, and diuretic effects. Objective: The aim of this research was to evaluate in vitro (anti-urease, antioxidant, anticholinesterase) and in vivo (anti-inflammatory) biological activities of caper (C. ovata var. canescens). In addition, we aimed to identify its major phenolic compounds using high performance liquid chromatography with a photodiode array detector (HPLC-DAD) and confirmate them using quadrupole time-of-flight liquid chromatography with tandem mass spectrometry (Q-TOF-LC/MS). Also, we quantified the concentrations of several trace and major elements in plant samples using inductively coupled plasma-mass spectrometry (ICP-MS). Methods: The antioxidant, anti-urease and anticholinesterase activities of different plant extracts were evaluated using DPPH, FRAP, ABTS/TEAC, Indophenol and Ellman tests. The identification of phenolic compounds and trace element contents was performed using HPLC and Q-TOF-LC/MS and ICP-MS. Results: Soxhlet methanol extract exhibited the strongest anti-urease, antioxidant (ABTS/TEAC) and anticholinesterase activity. Soxhlet and maceration methanol extracts demonstrated significant anti-inflammatory effect in the altered edema size after the second hour of carrageenan injection. The active phenolic compounds in Soxhlet methanol extract were identified as rutin, quercetin-hexoside-hexoside, quercetin-3-O-hexoside and kaempferol-3-O-rutinoside. In addition, the average concentrations of vanadium, chromium, manganese, cobalt, copper, nickel, arsenic, selenium, zinc and lead were within the permissible limits defined by WHO for medicinal plants. However, it was found that the concentrations of cadmium and iron were higher than the maximum permissible limits. Conclusion: Our results suggest that although caper has a strong biological activity, it should be consumed carefully due to the excess amount of cadmium and iron elements it contains.

Key words: Capparis ovata var. canescens, biological activity, HPLC-DAD, ICP-MS, liquid chromatography, mass spectrometry.

Taşkın, T., Taşkın, D., Çam, M.E., \& Bulut, G. (2020). Phenolic compounds, biological activities and trace elements of Capparis ovata var. canescens. Revista de Biología Tropical, 68(2), 590-600. 
Capparis species (Capparaceae), also called caper, grow naturally in various regions of the world. Caper is a plant with medicinal and aromatic properties. It grows naturally on all continents in many different regions of the world. Caper, which is called bubu, gebre, gabar, gevil, kapari, keper, kebere, tursuotu, and sebellah in different parts of Turkey, is an economically valuable plant. In various regions of the world, different organs of caper species have been used in a variety of ways since ancient times. Young shoots, flower buds and fruits are used in human nutrition.

Caper has an important role in the food industry; for instance, its flower buds are stored in brine and have become an expensive product during recent years. C. ovata grows widely in Mediterranean and Aegean regions of Turkey. Flower buds, root bark, and fruits of the plant are used in folk medicine due to their analgesic, wound healing, cell regeneration, tonic, and diuretic effects (Arslan \& Bektaş, 2010; Duman \& Ozcan, 2015). Capparis species contain quercetin, kaemferol, alkaloids, glucosinolate, lipid flavonoids, 5-hydroxymethylfurfural, 5-hydroxymethylfuroic acid, 2-furoic acid, protocolatechic acid, vanylic acid, succinic acid and 4-hydroxybenzoic acid (Yang et al., 2010). Capparis ovata Desf. var. canescens (Coss.) Heywood is a synonym of Capparis sicula Duhamel and buds of this species contain benzyl alcohol, furfural, ethanol methyl pentyl acetal, 4-vinyl guaiacol, thymol, octanoic acid and methyl isothiocyanate compounds. This species is also known to contain methyl isothiocyanate, thymol, 4-vinyl guaiacol, hexyl acetate and trans-teaspiran compounds in the leaves (Arslan \& Bektaş, 2010; Yang et al., 2010; Tülümen, 2011; Duman \& Ozcan, 2015). In humans, the endogenous defense system is inadequate to remove free radicals resulting from respiration and environmental factors (cigarettes, heavy metals, chemicals, etc.). Antioxidants are needed to contrast harmful effects from free radicals on human health (Asaka, Sepulveda, Sugiyama, \& Graham, 2001).

Helicobacter pylori is a gram-negative, moving, spiral-forming bacteria, and grows in microaerophilic atmosphere. The risk of gastric cancer in H. pylori positive people was 20 times higher than the negative ones. For this reason, $H$. pylori has been defined as class 1 carcinogen by the International Agency for Cancer Research (IACR). It is the only microorganism that can colonize the stomach $(\mathrm{pH}$ 4.5-6.5). Since the urease enzyme found in the bacteria produces an alkaline environment by breaking down the ammonia and carbon dioxide, the bacteria can survive there. Due to toxic effects of the medicaments used in therapy and the resistance of this bacterium to the antibiotics used in the treatment, there is a growing interest in naturally occurring products which contain the urease enzyme-inhibiting compound or active compounds (Kuwahara et al., 2000; Demiray \&Y1lmaz, 2007).

Alzheimer's disease (AD) is one of the most common neurodegenerative diseases. It is related with memory, learning abilities and life quality of individuals. This disease is expressed by the presence of $\beta$-amyloid plaque, intracellular neurofibrillary tangles (NFTs), synaptic deterioration and neuronal death. Although various drugs (rivastigmine, galantamine, donepezil, memantine, tacrine) are used for the treatment of $\mathrm{AD}$, their success in completely eliminating symptoms is low (Colovic, Krstić, Lazarević-Pašti, Bondžić, \& Vasić, 2013; Ulep, Saraon, \& McLea, 2018; Yildiz, Cam, Keles, Hazar-Yavuz, \& Kabasakal, 2019).

The selection of the extraction method to determine the potential activity of the extract is one of the most important factors, since the solvent polarity and extraction method determines which compounds will be extracted and which will not. Thus, in many cases of newly studied plants, various extracts are prepared using different extraction methods and solvents (Sasidharan, Chen, Saravanan, Sundram, \& Latha, 2011).

Although the plant is being used as food (pickled), there is no study of in vitro (antiurease, anticholinesterase) and in vivo (antiinflammatory) biological activities, or an analysis of the major phenolic compounds responsible for these activities. Therefore, the 
aim of this study was to evaluate in vitro antioxidant, anti-urease, anticholinesterase and in vivo anti-inflammatory activities of $C$. ovata var. canescens using a variety of extracts. Subsequently, we aimed to analyze the phenolic characterization of the Soxhlet methanol extract showing strong biological activity using high performance liquid chromatography with a photodiode array detector (HPLC-DAD) and liquid chromatography with tandem mass spectrometry (LC-MS/MS) techniques. In addition, we aimed to determine trace element contents with the inductively coupled plasma-mass spectrometry (ICP-MS) technique.

\section{MATERIAL AND METHODS}

Chemicals: Quercetin, 2,4,6-tripyridyls-triazine, 2,2-diphenyl-1-picryl-hydrazyl $\left(\mathrm{DPPH}^{\circ}\right)$ and ascorbic acid were obtained from Sigma Chemical Co. (2,2'-Azino-bis(3-ethylbenzothiazoline-6-sulfonate)) and butylated hydroxyanisole was sourced from Fluka. All other reagents were of analytical grade.

Plant material and preparation of plant extracts: Capparis ovata var. canescens specimens were collected in 2016 in Adryaman-Besni, Turkey. Voucher specimens were deposited in the herbarium of the Faculty of Pharmacy, Marmara University, Turkey; herbarium code number: MARE18469. The dried aerial parts of plants $(20 \mathrm{~g})$ were used for methanol extractions (CMM) by maceration at room temperature until obtaining a colorless solution. Fifty grams of plant powder were weighed into the Soxhlet extractor and extracted with $300 \mathrm{~mL}$ of petroleum ether (CSP), chloroform (CSC) and methanol (CSM) for $6 \mathrm{~h}$. The CMM $(350 \mathrm{~mL}), \mathrm{CSP}(300 \mathrm{~mL}), \mathrm{CSC}(300 \mathrm{~mL})$ and CSM $(300 \mathrm{~mL})$ filtrates obtained from the plant were concentrated with a rotary evaporator. All the extracts obtained were stored at $-20{ }^{\circ} \mathrm{C}$ for future analysis.

Extract yield percentage and total flavonoid contents: The extraction yield was calculated to determine the effect of the solvents to extract the active compounds from the plant material (Murugan \& Parimelazhagan, 2014). The percentage yield was obtained using this formula: $\%$ extract yield $=\mathrm{A}_{2}-\mathrm{A}_{1} /$ $A_{0} \times 100$; where $A_{2}$ is the weight of the extract and the container, $\mathrm{A}_{1}$ is the weight of the container alone and $\mathrm{A}_{0}$ the weight of the initial dried sample.

The total flavonoid content of the extract was determined using the aluminium chloride assay (Samatha, Shyamsundarachary, Srinivas, \& Swamy, 2012). Extract solution volumes of $0.5 \mathrm{~mL}$ were taken in different test tubes, then $2 \mathrm{~mL}$ of distilled water was added, followed by the addition of $0.15 \mathrm{~mL}$ of sodium nitrite $(5 \%$ $\mathrm{NaNO}_{2}, \mathrm{w} / \mathrm{v}$ ) and left to rest for $6 \mathrm{~min}$. Later, $0.15 \mathrm{~mL}$ of aluminium trichloride $\left(10 \% \mathrm{AlCl}_{3}\right)$ was added and incubated for $6 \mathrm{~min}$, followed by the addition of $2 \mathrm{~mL}$ of sodium hydroxide $(\mathrm{NaOH}, 4 \% \mathrm{w} / \mathrm{v})$ and volume was made upto the $5 \mathrm{~mL}$ with distilled water. The mixture was left standing at ambient temperature for $15 \mathrm{~min}$. Then, the absorbance was measured at $510 \mathrm{~nm}$ against a reagent blank. Total flavonoid contents was expressed as quercetin equivalents in milligram per milligram of extract (mg QuE/ mg extract).

DPPH radical scavenging activity: The ability of free radical scavenging of four different extracts was determined using the DPPH method. Briefly, $240 \mu \mathrm{L}$ of DPPH solution (0.1 $\mathrm{mM}$ ) was added to $10 \mu \mathrm{L}$ of extracts prepared at different concentrations $(0.5-5 \mathrm{mg} / \mathrm{mL})$. Then the mixture was allowed to stand at room temperature for $30 \mathrm{~min}$. The absorbance of the mixture was measured against the reference using a microplate reader (AMR-100) at 517 $\mathrm{nm}$. The experiment was repeated three times and the results obtained in the experiment were given as $\mathrm{IC}_{50}=\mathrm{mg} / \mathrm{mL}$ (Wei, Jinglou, Yaling, Yongfang, \& Liming, 2010).

Trolox equivalent antioxidant activity: Briefly, $40 \mu \mathrm{L}$ of four different extracts (0.5-5 $\mathrm{mg} / \mathrm{mL}$ ) prepared from plant material, $3960 \mu \mathrm{L}$ of $\mathrm{ABTS}^{*+}$ working solution were combined. The absorbance of the mixture was measured 
against the reference using UV spectrophotometer (Shimadzu UV-1800) at $734 \mathrm{~nm}$ for $6 \mathrm{~min}$. The standard curve was prepared using trolox and the data obtained in this study were expressed as $\mathrm{mM}$ trolox/mg extract (Re, Pellegrini, Proteggente, Pannala, \& Yang, 1999).

Ferric reducing/antioxidant power (FRAP) assay: The ability of ferric reducing of different extracts $(0.5-5 \mathrm{mg} / \mathrm{mL})$ was evaluated using the FRAP method. Briefly, $3.8 \mathrm{~mL}$ of FRAP reagent was mixed with $0.2 \mathrm{~mL}$ of extract and, after $4 \mathrm{~min}$, the absorbance of the mixture was measured against the reference using an UV spectrophotometer (Shimadzu UV-1800) at $593 \mathrm{~nm}$. The standard curve was prepared using $\mathrm{FeSO}_{4} \cdot 7 \mathrm{H}_{2} \mathrm{O}$ and $\mathrm{FRAP}$ values of the extracts were expressed as a $\mathrm{mM} \mathrm{Fe}^{2+}$ / mg extract (Benzie et al., 1996).

Anti-urease activity: Briefly, $500 \mu \mathrm{L}$ of urease enzyme was added to $100 \mu \mathrm{L}$ of the extracts and incubated at $37{ }^{\circ} \mathrm{C}$ for $30 \mathrm{~min}$. Then, $1100 \mu \mathrm{L}$ of urea was placed in this mixture and the mixture was incubated for $30 \mathrm{~min}$ at $37{ }^{\circ} \mathrm{C}$. $\mathrm{R}_{1}$ ( $1 \%$ phenol, $0.005 \%$ sodium nitroprusside) and $\mathrm{R}_{2}(0.5 \% \mathrm{NaOH}$, $0.1 \%$ sodium hypochlorite) reagents were added respectively to the mixture. The mixture was incubated for $2 \mathrm{~h}\left(37^{\circ} \mathrm{C}\right)$ and then the absorbance of the mixture was read at $635 \mathrm{~nm}$ against the reference using an UV spectrophotometer (Shimadzu UV-1800) (Ghous, Akhtar, Nasim, \& Choudhry, 2010).

Anticholinesterase activity of extracts: Inhibition of cholinesterases was evaluated using a 96-well microplate reader based on the method of Ellman, Courtney, Andress and Featherstone (1961) with some modifications. All reagent solutions (daily) were prepared using Tris-HCl buffer (50 mM, pH 8.0). Briefly, $20 \mu$ l of AChE solution were mixed with 20 $\mu \mathrm{l}$ of the sample and $40 \mu \mathrm{l}$ of Tris- $\mathrm{HCl}$ buffer and the mixture was left at room temperature $\left(25^{\circ} \mathrm{C}\right)$ for $10 \mathrm{~min}$. Then, $20 \mu \mathrm{l}$ of ATChI (50 $\mathrm{mM}$ ) was added the mixture and the mixture was incubated for $5 \mathrm{~min}$ at $25^{\circ} \mathrm{C}$. Then, 100 $\mu \mathrm{l}$ of $20 \mathrm{mM}$ DTNB (containing $1 \mathrm{M} \mathrm{NaCl}$ and $0.2 \mathrm{M} \mathrm{MgCl}_{2} \cdot 6 \mathrm{H}_{2} \mathrm{O}$ ) was added to the mixture and the absorbance of the mixture was read at $412 \mathrm{~nm}$ against the reference using an UV spectrophotometer (Shimadzu UV-1800). The experiments were performed in triplicate in each case. Galantamine was used as reference (Ellman et al., 1961).

\section{In vivo evaluation of anti-inflammato-} ry activity: Carrageenan-induced paw edema was induced in Sprague-Dawley rats by subplantar injection of $0.1 \mathrm{ml}$ of $1 \%(\mathrm{w} / \mathrm{v})$ carrageenan in the right paw. The different groups were treated orally with maceration methanol (CMM) and Soxhlet methanol extracts (CSM) of plant $(200 \mathrm{mg} / \mathrm{kg}$, p.o.), indomethacin (5 $\mathrm{mg} / \mathrm{kg}$, p.o.) and saline (10 ml/kg, p.o.) 60 min before the administration of carrageenan (Zhang, Dai, \& Cai, 2011; Naziroglu et al., 2013). The volume of the edema development and its duration was determined for $4 \mathrm{~h}$ using a plethysmometer (model \#37140 UgoBasile, Italy). The inhibitory activity was calculated according to the formula: \% Inhibition $=[(\mathrm{Vt}-$ Vo) control - (Vt-Vo)]/[(Vt-Vo) control] x 100; where $\mathrm{Vt}$ is the paw volume at time $\mathrm{t}$, Vo is the paw volume before carrageenan injection, (Vt-Vo) is edema in paw after time t. The study was approved by Marmara University, Animal Experiments Local Ethics Committee (MÜHDEK-58.2017.mar).

Analysis of phenolic compounds: The active phenolic compounds in Soxhlet methanol extract with strong biological activity were performed on an Shimadzu LC-20AT, using high performance liquid chromatography with a photodiode array detector (HPLC-DAD). The compounds were identified based on comparison on-line ultraviolet absorption spectrum data and retention times acquired with authentic standards (Halpine, 1996). A C18 analytical column (Nova-Pak C18; $3.9 \times 150 \mathrm{~mm}, 4 \mu \mathrm{m}$ ) was used to analysed the compounds. The system was operated at a flow rate of $0.5 \mathrm{~mL}$ $\min ^{-1}$ using a water/acetonitrile gradient with $0.1 \%$ trifluoroacetic acid. The compounds 
were confirmed by liquid chromatography with quadrupole time-of-flight mass spectrometry using targeted MS/MS techniques with accurate mass measurement. Phenolic compounds were identified and characterized by comparing maximum UV absorptions, HPLC retention time and MS-MS of target peaks in the extracts with the standards. Chromatographic peaks for phenolic compounds were selected by using the theoretical $[\mathrm{M}-\mathrm{H}]^{-}$as precursor ion. Tandem mass spectrometry (MS/MS) analysis of phenolic compounds was carried out in negative mode using electrospray ionization.

Analysis of trace elements: A plant sample $(5 \mathrm{mg})$ was weighed and mixed with $\mathrm{HNO}_{3}$ : $\mathrm{H}_{2} \mathrm{O}_{2},(3: 1 v / v)$. Then, $10 \mathrm{~mL}$ of this mixture was used and dissolved in the microwave $\left(0-180{ }^{\circ} \mathrm{C}\right)$ and was read using inductively coupled plasma mass spectrometry (ICP-MS). The ICP-MS instrument used was an Agilent 7 700 ICP-MS equipped with an ASX-500 autosampler. We used internal standards for each element to be analyzed, and a collision reaction cell to eliminate spectral and non-spectral interference. The required mode for each element was determined by the collision reaction cell.

Statistical analysis: All the experiments were done in triplicate. The results of the antioxidant, anticholinesterase and anti-urease experiments are shown as mean $\pm \mathrm{SD}$. All the data was analysed with the Graphpad Prism 5 program. Statistical differences between the study groups were analysed using two-way analysis of variance (ANOVA) followed by Tukey's Multiple Comparison test. The data obtained from anti-inflammatory activity were analyzed with PASW Statistics. We examined differences between means using Mann-Whitney $U$ tests and p-values less than 0.05 were considered statistically significant.

\section{RESULTS}

Extract yield percentage and total flavonoid contents: The total flavonoid contents and yield percentage of different extracts were analysed and presented in Table 1 . The results from the present study showed that the total flavonoid contents in Soxhlet chloroform extract were higher than other extracts. In addition, maceration methanol extract had higher amount total flavonoids contents than Soxhlet methanol extract. When the yield percentage of the different extracts is compared, Soxhlet methanol extract had higher recovery over other extracts.

TABLE 1

Extract yield percentage and total flavonoid contents of Capparis ovata var. canescens

\begin{tabular}{ccc} 
& $\begin{array}{c}\text { Total flavonoid } \\
(\mathrm{mg} \text { QUE/mg extract) }\end{array}$ & $\begin{array}{c}\text { Extract yield } \\
(\%)\end{array}$ \\
CSP & $2.15 \pm 0.03^{\mathrm{a}}$ & $20.6^{\mathrm{a}}$ \\
$\mathrm{CSC}$ & $3.74 \pm 0.11^{\mathrm{b}}$ & $7.91^{\mathrm{b}}$ \\
$\mathrm{CSM}$ & $0.56 \pm 0.02^{\mathrm{c}}$ & $87.0^{\mathrm{c}}$ \\
CMM & $1.57 \pm 0.11^{\mathrm{d}}$ & $26.68^{\mathrm{d}}$ \\
\hline
\end{tabular}

Values are means of triplicates $\pm \mathrm{SD}$; means with different superscripts $(\mathrm{a}-\mathrm{d})$ are significantly different $(\mathrm{P}<0.05)$. QUE $=$ Quercetin equivalents, CSP $=$ Soxhlet petroleum ether extract, $\mathrm{CSC}=$ Soxhlet chloroform extract, $\mathrm{CSM}=$ Soxhlet methanol extract, $\mathrm{CMM}=$ Maceration methanol extract.

Antioxidant activity of extracts: The antioxidant activities of different extracts are shown in Table 2. The maceration methanol $\left(\mathrm{IC}_{50}=0.12 \pm 0.03 \mathrm{mg} / \mathrm{mL}\right)$ and Soxhlet methanol $\left(\mathrm{IC}_{50}=0.22 \pm 0.04 \mathrm{mg} / \mathrm{mL}\right)$ extracts exhibited the strongest free radical scavenging activity. The chloroform extract showed the lowest DPPH free radical scavenging activity. As shown in Table 2, the radical scavenging DPPH activities of all extracts were lower than that of ascorbic acid $\left(\mathrm{IC}_{50}=0.006 \pm 0.01 \mathrm{mg} /\right.$ $\mathrm{mL})$. The Soxhlet methanol (16.36 mM trolox/ $\mathrm{mg}$ extract), and Soxhlet chloroform (11.26 $\mathrm{mM}$ trolox/mg extract) extracts showed stronger ABTS radical cation scavenging activity than other extracts. The petroleum ether extract (3.75 mM trolox/mg extract) had the lowest ABTS radical cation scavenging activity. In this study, when we compare the extraction techniques, it has been found that the extracts obtained by Soxhlet and maceration showed 
TABLE 2

Antioxidant activity of Capparis ovata var. canescens extracts

\begin{tabular}{lccc}
\multicolumn{1}{c}{ Samples } & $\begin{array}{c}\mathrm{DPPH} \\
\left(\mathrm{IC}_{50}=\mathrm{mg} / \mathrm{mL}\right)\end{array}$ & $\begin{array}{c}\text { ABTS } \\
(\mathrm{mM} \text { trolox/mg extract })\end{array}$ & $\begin{array}{c}\text { FRAP assay } \\
\left(\mathrm{mM} \mathrm{Fe}^{2+} / \mathrm{mg} \mathrm{extract}^{2}\right)\end{array}$ \\
CSP & $0.5 \pm 0.15^{\mathrm{a}}$ & $3.75 \pm 0.05^{\mathrm{a}}$ & $6.97 \pm 0.004^{\mathrm{a}}$ \\
$\mathrm{CSC}$ & $0.67 \pm 0.58^{\mathrm{b}}$ & $11.26 \pm 0.001^{\mathrm{b}}$ & $5.513 \pm 0.23^{\mathrm{b}, \mathrm{a}}$ \\
$\mathrm{CSM}$ & $0.22 \pm 0.03^{\mathrm{c}}$ & $16.36 \pm 0.06^{\mathrm{c}}$ & $5.515 \pm 0.03^{\mathrm{c}, \mathrm{a}, \mathrm{b}}$ \\
$\mathrm{CMM}$ & $0.12 \pm 0.03^{\mathrm{d}}$ & $7.67 \pm 0.01^{\mathrm{d}}$ & $5.13 \pm 0.02^{\mathrm{d}, \mathrm{a}, \mathrm{b}, \mathrm{c}}$ \\
Ascorbic acid & $0.006 \pm 0.01^{\mathrm{e}}$ & & \\
BHA & & $52.63 \pm 0.01^{\mathrm{e}}$ & $16.91 \pm 0.02^{\mathrm{e}}$ \\
\hline
\end{tabular}

Values are means of triplicates $\pm \mathrm{SD}$; means with different superscripts (a-e) are significantly different $(\mathrm{P}<0.05)$. BHA $=$ butylated hydroxyanisole, $\mathrm{CSP}=$ Soxhlet petroleum ether extract, $\mathrm{CSC}=$ Soxhlet chloroform extract, $\mathrm{CSM}=\mathrm{Soxhlet}$ methanol extract, $\mathrm{CMM}=$ maceration methanol extract.

strong DPPH and ABTS radical scavenging activity. In this study, Soxhlet petroleum ether (6.97 $\mathrm{mM} \mathrm{Fe}^{2+} / \mathrm{mg}$ extract) and Soxhlet methanol $\left(5.515 \mathrm{mM} \mathrm{Fe}{ }^{2+} / \mathrm{mg}\right.$ extract) extracts was found to have stronger ferric reducing activity the other extracts. The soxhlet methanol and maceration methanol extracts showed very close ferric reducing activity. The results obtained from this study showed that both extraction techniques are the most suitable method to get the most powerful ferric reducing activity.

\section{Urease and cholinesterase inhibitory} activity: The results of anti-urease and anticholinesterase activity of different extracts are shown in Table 3. The Soxhlet methanol (23.95 $\%)$ extract exhibited the strongest anti-urease activity. In this study also found that maceration methanol extract had lower anti-urease activity than other extracts. According to this study, all the extracts had lower anti-urease activity than thiourea $(97.035 \%)$. The Soxhlet methanol (45.79 \%) extract exhibited the strongest anticholinesterase activity. Soxhlet chloroform extract didn't show cholinesterase inhibitory activity. According to this study, all the extracts had lower anticholinesterase activity than galantamine $(88.14 \%, 200 \mu \mathrm{g} / \mathrm{mL})$. In the present study, Soxhlet methanol methods/ solvents were the most suitable solvents and methods to get the strongest anti-urease and anticholinesterase activity.

In vivo evaluation of anti-inflammatory activity: The paw volume was altered by the injection of carrageenan, reaching the maximum 4 h post-injection (Vazquez et al., 2015). Indomethacin $(5 \mathrm{mg} / \mathrm{kg})$ demonstrated maximum anti-inflammatory effect $(90.41 \%)$ at $4 \mathrm{~h}$

TABLE 3

Enzyme inhibitory activity of different Capparis ovata var. canescens extracts

\begin{tabular}{|c|c|c|}
\hline Samples & Urease inhibition (\%) $(25 \mu \mathrm{g} / \mathrm{mL})$ & Cholinesterase inhibition (\%) $(500 \mu \mathrm{g} / \mathrm{mL})$ \\
\hline CSP & $19.93 \pm 1.05^{\mathrm{a}}$ & $31.04 \pm 1.8^{\mathrm{a}}$ \\
\hline $\mathrm{CSC}$ & $18.54 \pm 1.02^{\mathrm{b}}$ & NA \\
\hline $\mathrm{CSM}$ & $23.95 \pm 0.9^{c}$ & $45.79 \pm 0.69^{b}$ \\
\hline CMM & $16.80 \pm 0.99^{d}$ & $19.00 \pm 0.75^{\mathrm{c}}$ \\
\hline Thiourea & $97.04 \pm 0.14^{\mathrm{e}}$ & \\
\hline Galantamine $(200 \mu \mathrm{g} / \mathrm{mL})$ & & $88.14 \pm 0.14^{\mathrm{d}}$ \\
\hline
\end{tabular}

Values are means of triplicates $\pm \mathrm{SD}$; means with different superscripts (a-e) are significantly different $(\mathrm{P}<0.05)$. NA $=$ no activity, $\mathrm{CSP}=$ Soxhlet petroleum ether extract, $\mathrm{CSC}=$ Soxhlet chloroform extract, $\mathrm{CSM}=$ Soxhlet methanol extract, $\mathrm{CMM}$ $=$ maceration methanol extract. 
TABLE 4

Inhibition percentage of paw edema in metanol extracts of Capparis ovata var. canescens

\begin{tabular}{lcccc}
\multicolumn{1}{c}{ Treatment } & $60 \mathrm{~min}$ & $120 \mathrm{~min}$ & $180 \mathrm{~min}$ & $240 \mathrm{~min}$ \\
CSM (\%) & 36.53 & 78.58 & 26.32 & 35.06 \\
CMM (\%) & 53.19 & 60.39 & 66.35 & 37.40 \\
Indomethacin (\%) & 36.88 & 82.23 & 82.90 & 90.41 \\
\hline
\end{tabular}

$\mathrm{CSM}=$ Soxhlet methanol extract, $\mathrm{CMM}=$ maceration methanol extract.

after carrageenan injection (Table 4, $\mathrm{P}<0.001$ ). Maceration methanol extract (CMM) demonstrated a more prominent and intensive anti-inflammatory effect at first hour after carrageenan injection with $53.19 \%$ compared to Soxhlet methanol extract (CSM) $(36.53 \%)$ during $3 \mathrm{~h}$ with an gradual increase, reaches $66.35 \%$ of inhibitory capacity in the altered edema size after $3 \mathrm{~h}$. However, CSM's inhibitory effect was not strong in the first hour but it reached maximum by $78.58 \%$ inhibition in second hour $(\mathrm{P}<0.001)$ and it lost the effect by third hour (Table 4). There was a significant $(\mathrm{P}<0.05)$ difference between $\mathrm{CMM}$ and indomethacin group Besides, CSM lost its antiinflammatory effect by fourth hour compared to indomethacin group $(\mathrm{P}<0.001)$. Carrageenan-induced edema is largely used as an experimental animal model in the consideration of acute inflammation and is thought to be biphasic, of which the first phase is mediated by the release of histamine and 5- hydroxytryptamine pursued by kinin release and then prostaglandin in the later phase (Alcaraz \& Jimenez, 1988). Acute single-dose of CMM and CSM significantly decreased rat paw edema volume, especially at $2 \mathrm{~h}$ after carrageenan injection. Some phenolic compounds have been reported to conceive inhibition of histamine release in mast cells, which is responsible for early phase of inflammation induced by carrageenan (Jabeur et al., 2017). Consequently, CMM and CSM's acute anti-inflammatory effects may be based upon their phenolic composition, which trigger the anti-inflammatory action, but further investigations are needed to identify precise mechanisms.
Analysis of phenolic compounds: In this study, phenolic compounds in Soxhlet methanol extract, which exhibited strong biological activity were analysed by HPLC-DAD based on comparing on-line ultraviolet absorption spectrum data and retention times acquired with authentic standards. After that, they were confirmed by liquid chromatography with quadrupole time-of-flight mass spectrometry using targeted MS/MS techniques with accurate mass measurement. They were identified as rutin, quercetin-hexoside-hexoside, quercetin-3-O-hexoside and kaempferol-3-Orutinoside. To the best of our knowledge, there are some reports in literature on the chemical contents of this species. It is known that this species contains protein, lipid, vitamin, amino acid, sugar and benzyl alcohol, furfural, 4-vinyl guaiacol, thymol, methyl isothiocyanate, hexyl acetate compounds is isolated from its seeds and leaves (Tülümen, 2011). In contrast to the above study, in our study, the phenolic compounds responsible for biological activity of this species were for the first time analyzed by HPLC-DAD and LC-MS/MS. As a result of this study, rutin, quercetin-hexoside-hexoside, quercetin-3-O-hexoside and kaempferol-3-Orutinoside were analysed the first time in Soxhlet methanol extract from the aerial parts of the plant (Table 5).

Analysis of trace element of plant: The average concentrations of vanadium, chromium, manganese, cobalt, copper, nickel, arsenic, selenium, zinc, lead were within the permissible limits defined by the World Health Organization (WHO) for medicinal plants. However, 
TABLE 5

Identification of phenolic compounds in Soxhlet methanol extracts of Capparis ovata var. canescens

\begin{tabular}{|c|c|c|c|c|}
\hline Compounds & Rt (min) & Empirical Formula & {$[\mathrm{M}-\mathrm{H}]^{-}$} & Major and important $\mathrm{MS}^{2}$ ions \\
\hline Rutin* & 14.921 & $\mathrm{C}_{27} \mathrm{H}_{30} \mathrm{O}_{16}$ & 609.1504 & $300,271,255,151$ \\
\hline Quercetin-hexoside-hexoside ${ }^{\mathrm{a}}$ & 15.131 & $\mathrm{C}_{27} \mathrm{H}_{30} \mathrm{O}_{16}$ & 625.1444 & $301,344,271,155$ \\
\hline Quercetin-3-O-hexoside ${ }^{\mathrm{b}}$ & 15.316 & $\mathrm{C}_{21} \mathrm{H}_{20} \mathrm{O}_{12}$ & 463.0908 & $300,271,255,227,179,151$ \\
\hline Kaempferol-3-O-rutinoside ${ }^{\mathrm{c}}$ & 16.52 & $\mathrm{C}_{27} \mathrm{H}_{30} \mathrm{O}_{15}$ & 593.1553 & $285,284,255,227,179$ \\
\hline
\end{tabular}

* Identified with authentic compounds.

a,b,c Identified by related literature (Chen, Inbaraj, \& Chen, 2012; Gu et al., 2013; Martini, Conte, \& Tagliazucchi, 2018).

TABLE 6

Trace element contents in samples of Capparis ovata var. canescens based on inductively coupled plasma-mass spectrometry

\begin{tabular}{cccccc} 
Element & Mass & Tune Mode $^{\mathrm{a}}$ & ISTD & Conc* $(\mathrm{mg} / \mathrm{kg})$ & Integration Time/Mass (s) \\
$\mathrm{V}$ & 51 & $\mathrm{He}$ & - & $0.28 \pm 0.01$ & 0.50 \\
$\mathrm{Cr}$ & 52 & $\mathrm{He}$ & $\mathrm{Sc}$ & $0.64 \pm 0.03$ & 1.00 \\
$\mathrm{Mn}$ & 55 & $\mathrm{He}$ & $\mathrm{Sc}$ & $59.96 \pm 3.44$ & 0.10 \\
$\mathrm{Fe}$ & 56 & $\mathrm{He}$ & $\mathrm{Sc}$ & $136.01 \pm 10.28$ & 0.10 \\
$\mathrm{Co}$ & 59 & $\mathrm{He}$ & $\mathrm{Sc}$ & $0.23 \pm 0.01$ & 0.10 \\
$\mathrm{Ni}$ & 60 & $\mathrm{He}$ & $\mathrm{Sc}$ & $1.54 \pm 0.04$ & 1.00 \\
$\mathrm{Cu}$ & 63 & $\mathrm{He}$ & $\mathrm{Sc}$ & $6.54 \pm 0.51$ & 0.20 \\
$\mathrm{Zn}$ & 66 & $\mathrm{He}$ & $\mathrm{Ge}$ & $48.67 \pm 1.83$ & 0.10 \\
$\mathrm{As}$ & 75 & $\mathrm{He}$ & $\mathrm{Ge}$ & $<0.004$ & 5.00 \\
$\mathrm{Se}$ & 78 & $\mathrm{He}$ & $\mathrm{Ge}$ & $0.74 \pm 0.04$ & 1.00 \\
$\mathrm{Cd}$ & 111 & No Gas & $\mathrm{In}$ & $0.67 \pm 0.03$ & 0.30 \\
$\mathrm{~Pb}$ & 208 & No Gas & $\mathrm{Bi}$ & $0.15 \pm 0.01$ & \\
\hline
\end{tabular}

$* \mathrm{n}=4$ replicates.

it was found that the concentrations of cadmium and iron were beyond the maximum permissible limits set by WHO. The permissible limit of cadmium in plants, recommended by $\mathrm{WHO}$, is $0.3 \mathrm{mg} / \mathrm{kg}$ (Eludoyin \& Ogbe, 2017). In plant samples concentration of cadmium was recorded above the permissible limit set by WHO. The WHO recommended level of iron in plants is $20 \mathrm{mg} / \mathrm{kg}$ (Shah et al., 2013). In plant samples concentration of iron was above the permissible limit set by WHO (Table 6).

\section{DISCUSSION}

According to literature reviews, there are some studies on antioxidant activity of Capparis ovata var. canescens. The antioxidant activity (TEAC method) and total phenolic content of methanol extract obtained from Soxhlet method from plant young shoots were investigated by Özcan, Özcan and Emine (2009). According to the results of the experiment, the TEAC value of methanol extract was found to be $0.6024 \mu \mathrm{mol}$ trolox equivalent/g dry weight. In addition, in this experiment, it was determined that methanol extract contained 1.3175 $\mathrm{mg}$ of GAE/g extract phenolic content (Özcan et al., 2009).

In another study, antioxidant activities of dichloromethane and methanol extracts obtained from plant buds and leaves were evaluated by the DPPH radical scavenging activity method. According to the obtained data, the methanol extract from the leaves (99.6 $\%$ ) showed a stronger DPPH radical scavenging activity than the buds extracts (El-Ghorab, 
Shibamoto, \& Özcan, 2007). In contrast to the above study, in our study, we examined the total flavonoids contents and antioxidant activity (DPPH, FRAP, ABTS/TEAC) of four different extracts (Soxhlet petroleum ether, Soxhlet chloroform, Soxhlet methanol and maceration methanol extracts) obtained using different extraction methods. In addition, the effects of extraction methods/solvents on antioxidant activity were examined in this study. When the results obtained from the TEAC radical scavenging assay were compared with results of ours, it was found that Soxhlet methanol extract from aerial parts exhibited stronger ABTS radical scavenging activity than Soxhlet methanol extract from young shoots. It was also found that leaves methanol extract showed similar free radical activity to aerial parts methanol extracts. The results obtained from our study showed that Soxhlet methanol extraction technique is the most suitable method/solvent to get the most powerful ferric reducing and ABTS radical scavenging activity.

To the best of our knowledge, there have been no reports in the literature on the antiurease and anticholinesterase activity of different extracts from aerial parts of this species. Therefore, the purpose of this study was to examine for the first time the anti-urease and anticholinesterase activity of this species's extracts obtained using different extraction methods and also to determine the most suitable extraction method and solvents. There have been no studies on anti-inflammatory activities of maceration and Soxhlet methanol extracts from plant's aerial parts. In this study, anti-inflammatory activity of extracts was examined for the first time and according to the obtained results, acute single-dose of both extracts from plant significantly decreased rat paw edema volume, especially at $2 \mathrm{~h}$ after carrageenan injection.

Concentration of all trace and major elements apart from $\mathrm{Fe}$ and $\mathrm{Cd}$ were found below the permissible limits recommended by WHO for medicinal plants. Fe levels were above the permissible limits set by WHO in medicinal plants as many scientific articles have been published. Excessive iron loading to the human body causes some diseases such as liver damage, nausea and vomiting, diarrhea etc. Cadmium can accumulate in many organs, including liver and kidney, and adversely affect the functions of these organs (Yang \& Shu, 2015). Cd contamination of plants comes from the use of phosphate fertilizers (Eludoyin \& Ogbe, 2017). Due to the high cadmium and iron content of the plant, it is necessary to be careful about its consumption (Nkuba \& Mohammed, 2017).

In summary, we examined for the first time in vitro (anti- urease, anticholinesterase) and in vivo (anti-inflammatory) biological activities of C. ovata var. canescens, and analyzed the major phenolic compounds and trace element contents of the plant. According to the results obtained from this study, Soxhlet methanol extract exhibited strongest anti-urease, antioxidant (ABTS/TEAC) and anticholinesterase activity. Soxhlet and maceration methanol extracts demonstrated significant anti-inflammatory effects in the altered edema size after the second hour of carrageenan injection, but the anti-inflammatory effect of maceration methanol extract of plant continued longer compared to the Soxhlet methanol extract. The active phenolic compounds in Soxhlet methanol extract were identified as rutin, quercetinhexoside-hexoside, quercetin-3-O-hexoside and kaempferol-3-O-rutinoside. The concentration of $\mathrm{Fe}$ and $\mathrm{Cd}$ elements was above the permissible limits recommended by WHO for medicinal plants. The results obtained from this study suggest that although the plant has strong biological activity, it should be consumed carefully due to the excess amount of cadmium and iron elements it contains.

Ethical statement: The authors declare that they have not known competing financial interests or personal relationships that could have appeared to influence the work reported in this paper. 


\section{ACKNOWLEDGMENTS}

Gizem Bulut, from the Department of Pharmaceutical Botany at Marmara University, authenticated the Capparis ovata var. canescens specimens.

\section{RESUMEN}

Compuestos fenólicos, actividades biológicas y elementos traza de Capparis ovata var. canescens. Introducción: Las especies de Capparis (Capparaceae), también llamadas alcaparras, crecen naturalmente en varias regiones del mundo. La alcaparra es una planta con propiedades medicinales y aromáticas. Los botones florales, la corteza de la raíz y los frutos de la planta se usan en la medicina popular debido a sus efectos analgésicos, cicatrizantes, de regeneración celular, tónicos y diuréticos. Objetivo: El objetivo de esta investigación fue evaluar las actividades biológicas in vitro (anti-ureasa, antioxidante, anticolinesterasa) e in vivo (antiinflamatorio) de la alcaparra (C. ovata var. canescens). Además, nuestro objetivo fue identificar sus principales compuestos fenólicos mediante cromatografía líquida de alto rendimiento con un detector de matriz de fotodiodos (HPLC-DAD) y confirmarlos mediante cromatografía líquida con espectrometría de masas en tándem (Q-TOF-LC/MS). Además, cuantificamos las concentraciones de varios elementos traza y elementos mayores en muestras de la planta utilizando espectrometría de masas con plasma acoplado inductivamente (ICP-MS). Métodos: Se evaluaron las actividades antioxidantes, anti-ureasa y anticolinesterasa de diferentes extractos de la planta usando las pruebas DPPH, FRAP, ABTS/TEAC, Indofenol y Ellman. La identificación de los compuestos fenólicos y el contenido de los elementos traza se realizó mediante HPLC y Q-TOF-LC/MS e ICP-MS. Resultados: el extracto de metanol Soxhlet exhibió la mayor actividad anti-ureasa, antioxidante (ABTS/TEAC) y anticolinesterasa. Los extractos de metanol Soxhlet y por maceración demostraron un efecto antiinflamatorio significativo en el tamaño alterado del edema después de la segunda hora de la inyección de carragenano. Los compuestos fenólicos activos en el extracto de metanol Soxhlet se identificaron como rutina, quercetina-hexósido-hexósido, quercetina3-O-hexósido y kaempferol-3-O-rutinósido. Además, las concentraciones promedio de vanadio, cromo, manganeso, cobalto, cobre, níquel, arsénico, selenio, zinc y plomo estaban dentro de los límites permisibles definidos por la OMS para las plantas medicinales. Sin embargo, se encontró que las concentraciones de cadmio y hierro fueron más altas que los límites máximos permitidos. Conclusión: Nuestros resultados sugieren que, aunque la alcaparra tiene una fuerte actividad biológica, debe consumirse con cuidado debido al exceso de cadmio y hierro que contiene.
Palabras clave: Capparis ovata var. canescens, actividad biológica, HPLC-DAD, ICP-MS, cromatografía líquida, espectrometría de masas.

\section{REFERENCES}

Alcaraz, M.J., \& Jimenez, M.I. (1988). Flavonoid as antiinflammatory agents. Fitoterapia, 59, 25-38.

Arslan, R., \& Bektaş, N. (2010). Antinociceptive effect of methanol extract of Capparis ovata in mice. Pharmaceutical Biology, 48(10), 1185-1190.

Asaka, M., Sepulveda, A.R., Sugiyama, T., \& Graham, D.Y. (2001). Gastric Cancer. In H.L.T Mobley, G.L. Mendz, \& S.L. Hazell (Eds.), Helicobacter pylori: Physiology and Genetics (pp. 481-498). Washington, DC: ASM Press.

Benzie, I.F., \& Strain, J.J. (1996). The ferric reducing ability of plasma (FRAP) as a measure of "antioxidant power": the FRAP assay. Analytical Biochemistry, 239, 70-76.

Chen, H.J., Inbaraj, B.S., \& Chen, B.H. (2012). Determination of phenolic acids and flavonoids in Taraxacum formosanum Kitam by liquid chromatographytandem mass spectrometry coupled with a post-column derivatization technique. International Journal of Molecular Sciences, 13, 260-285.

Colovic, M.B., Krstić, D.Z., Lazarević-Pašti, T.D., Bondžić, A.M., \& Vasić, V.M. (2013). Acetylcholinesterase inhibitors: pharmacology and toxicology. Current Neuropharmacology, 11, 315-335.

Demiray, E., \& Yılmaz, Ö. (2007). The importance and the role of urease enzyme in Helicobacter pylori infection. Turkish Microbiological Society, 37(2), 112-117.

Duman, E., \& Özcan, M.M. (2015). Physicochemical properties of caper species seed oils collected from two different harvest years. Journal of the Science Food and Agriculture, 95, 2965-2972.

El-Ghorab, A., Shibamoto, T., \& Özcan, M.M. (2007). Chemical composition and antioxidant activities of buds and leaves of capers (Capparis ovata Desf. var. canescens) cultivated in Turkey. Journal of Essentiol Oil Research, 19, 72-77.

Ellman, G.L., Courtney, K.D., Andress, V., \& Featherstone, R.M. (1961). A new and rapid colorimetric determination of acetylcholinesterase activity. Biochemistry Pharmacology, 7, 88-95.

Eludoyin, O.S., \& Ogbe, O.M. (2017). Assessment of heavy metal concentrations in pawpaw (Carica papaya Linn.) around automobile workshops in port 
harcourt metropolis, Rivers State, Nigeria. Journal of Health \& Pollution, 7(14), 48-61.

Ghous, T., Akhtar, K., Nasim, F.U.H., \& Choudhry, M.A. (2010). Screening of selected medicinal plants for urease inhibitory activity. Biology and Medicine, 2, 64-69.

Gu, D., Yang, Y., Bakri, M., Chen, Q., Xin, X., \& Aisa, H.A. (2013). A LC/QTOF-MS/MS application to investigate chemical compositions in a fraction with protein tyrosine phosphatase 1B inhibitory activity from Rosa rugosa flowers. Phytochemical Analysis, 24, 661-670.

Halpine, S.M. (1996). An improved dye and lake pigment analysis method for high performance liquid chromatography and diode-array detector. Studies in Conservation, 41(2), 76-94.

Jabeur, I., Martins, N., Barros, L., Calhelha, R.C., Vaz, J., Achour, L., ... Ferreira, I.C.F.R. (2017). Contribution of the phenolic composition to the antioxidant, antiinflammatory and antitumor potential of Equisetum giganteum L. and Tilia platyphyllos Scop. Food Function, 8, 975-984.

Kuwahara, H., Yoichi, M., Takaaki, A., Tatsuo, K., Tomohiro, S., Shinichiro, O., \& Hiroshi, M. (2000). Helicobacter pylori urease suppresses bactericidal activity of peroxynitrite via carbon dioxide production. Infection and Immunity, 68(8), 4378-4383.

Martini, S., Conte, A., \& Tagliazucchi, D. (2018). Comprehensive evaluation of phenolic profile in dark chocolate and dark chocolate enriched with Sakura green tea leaves or turmeric powder. Food Research International, 112, 1-16.

Murugan, R., \& Parimelazhagan, T. (2014). Comparative evaluation of different extraction methods for antioxidant and anti-inflammatory properties from Osbeckia parvifolia Arn. - An in vitro approach. Journal of King Saud University-Science, 26(4), 267-275.

Naziroglu, M., Akay, M.B., Celik, O., Yildirim, M.I., Balci, E., \& Yurekli, V.A. (2013). Capparis ovata modulates brain oxidative toxicity and epileptic seizures in pentylentetrazol-induced epileptic rats. Neurochemistry Research, 38(4), 780-78.

Nkuba, L.L., \& Mohammed, N.K. (2017). Heavy metals and essential elements in selected medicinal plants commonly used for medicine in Tanzania. Chemical Science International Journal, 19(2), 1-11.

Özcan, M.M., Özcan, E., \& Emine, E.H. (2009). Antioxidant activity, phenolic content, and peroxide value of essential oil and extracts of some medicinal and aromatic plants used as condiments and herbal teas in Turkey. Journal of Medicine Food, 12(1), 198-202.

Re, R.N., Pellegrini, A., Proteggente, A., Pannala, M., \& Yang, C.R.E. (1999). Antioxidant activity applying an improved ABTS radical cation decolorization assay. Free Radical Biology Medicine, 26, 1231-1237.

Samatha, T., Shyamsundarachary, R., Srinivas, R.P., \& Swamy, N.R. (2012). Quantification of total phenolic and total flavonoid contents in extracts of Oroxylum indicum L. Kurz. Asian Journal of Pharmaceutical and Clinical Research, 5(4), 177-179.

Sasidharan, S., Chen, Y., Saravanan, D., Sundram, K.M., \& Latha, L.Y. (2011). Extraction, isolation and characterization of bioactive compounds from plants' extracts. African Journal of Traditional Complement Alternative Medicine, 8(1), 1-10.

Shah, A., Niaz, A., Ullah, N., Rehman, A., Akhlaq, M., Zakir, M., \& Khan, M.S. (2013). Comparative study of heavy metals in soil and selected medicinal plants. Journal of Chemistry, 2013, 1-5.

Tülümen, T. (2011). Investigation of the protective effects of Capparis ovata on experimental hepatotoxicity and oxidative stress induced by 6-mercaptopurine (Master Thesis). Süleyman Demirel University, Turkey.

Ulep, M.G., Saraon, S.K., \& McLea, S. (2018). Alzheimer Disease. The Journal for Nurse Practitioners, 14, 129-135.

Vazquez, E., Navarro, M., Salazar, Y., Crespo, G., Bruges, G., Osorio, C., ... Lopez, M. (2015). Systemic changes following carrageenan-induced paw inflammation in rats. Inflammation Research, 64, 333-342.

Wei, F.C., Jinglou, C., Yaling, L., Yongfang, C., \& Liming, P.L. (2010). Antioxidant, free radical scavenging, anti-inflammatoryand hepatoprotective potential of the extract from Parathelypteris nipponica (Franch. et Sav.) Ching. Journal of Ethnopharmacology, 130, 521-528.

Yang, H., \& Shu, Y. (2015). Cadmium transporters in the kidney and cadmium-induced nephrotoxicity. International Journal of Molecular Sciences, 16, 1484-1494.

Yang, T., Wang, C.H., Chou, G.X., Wu, T., Cheng, X.M., \& Wang, Z.T. (2010). New alkaloids from Capparis spinosa: Structure and X-ray crystallographic analysis. Food Chemistry, 123(3), 705-710.

Yildiz, S., Cam, M.E., Keles, R., Hazar-Yavuz, A.N., \& Kabasakal, L. (2019). A PPAR-alpha agonist gemfibrozil ameliorates cognitive and memory impairments in a sporadic Alzheimer's disease rat model. European Neuropsychopharmacology, 29(Suppl. 1), S263-S264.

Zhang, C.X., Dai, Z.R., \& Cai, Q.X. (2011). Anti-inflammatory and anti-nociceptive activities of Sipunculus nudus L. extract. Journal of Ethnopharmacology, 137(3), 1177-1182. 